\title{
SOCIAL SECURITY AND THE LAW OF DISMISSAL
}

\author{
John Hughes \\ Canterbury University
}

\begin{abstract}
The sweeping changes made to social security law following the election of the National Government in 1990 have had major repercussions on employment law. This paper examines the developing law on matters such as the 26 week 'stand down' for workers dismissed for misconduct, in the light of decisions of the Social Security Appeal Authority and the Employment Court and policy guidelines formulated by the Department of Social Welfare and the New Zealand Employment Service.
\end{abstract}

Since social security benefits for the unemployed were first introduced, argument has taken place as to the effect, if any, of the existence of the benefit on the 'will to work'. The debate has taken many forms, but has tended to centre on the relative economic advantage, if any, of receiving a benefit as against a low wage, and perceived corresponding disincentives to take poorly paid or unpleasant jobs.

Of less importance in policy terms, but of obvious weight in terms of those holding jobs which they are about to lose, are the sanctions provided by the social security system for those unemployed people who are seen as having abandoned work voluntarily or as having lost work because of reasons within their own control (for example, after being dismissed for misconduct). It is this latter area which will form the basis for discussion in this paper.

\section{The introduction of mandatory sanctions}

Under the now-repealed s 60(6) of the Social Security Act 1964 there was discretionary authority to postpone the commencement of the unemployment benefit for a period not exceeding six weeks, or to terminate any benefit already granted where, amongst other things, the applicant had voluntarily become unemployed without a good and sufficient reason; or had lost his or her employment by reason of any misconduct as a worker.

These conditions, which were seen to "test the worthiness of the individual to receive the benefit" (Department of Social Welfare, 1971) provided the most controversial aspect of the administration of the unemployment benefit. The underlying rationale of $s 60(6)$ was that qualifying unemployment must be the result of extrinsic considerations rather than resulting from the applicant's or beneficiary's own volition or state of health (Hughes, 1990, 13175). The maximum six week period of non-entitlement was rarely imposed.
Shortly after the election of the National Government in 1990 , the period of non-entitlement was changed from a maximum of six weeks (which was only rarely imposed in practice) to a mandatory period of 26 weeks. This new provision resulted from a proposal by the Minister of Social Welfare in a Report to the Cabinet Strategy Committee "to provide a clear message that anyone voluntarily unemployed cannot expect to look to the welfare system for continued support" (Shipley, 1990a, 4). The Report had expressed suspicion that the earlier discretionary system was encouraging manipulation and careless administration. Introducing the bill, the Minister stated that "Individuals must take responsibility for their own actions where they put their own jobs in jeopardy through misconduct, or where they give up an income without first securing an alternative source of income" (Shipley, 1991a, 4). However, the Treasury Brief to the Incoming Government, in dealing with Social Welfare, had viewed the issue of stand-down periods in terms of allocation of risk:

Avoidable risk is best carried by those who can influence it and unavoidable risk carried by those best placed to insure against it. The former suggests that ... beneficiaries should probably face some direct costs of social services when they can influence their demand for these services ... This can be achieved using instruments like stand-down periods for benefits. (NZ Treasury, 1990, 98)

Apparently, however, the mandatory six-month standdown was proceeded with against Treasury advice (Stephens, 1992). Whilst the Minister of Labour at the time, the Hon WB Birch, denied that the social security changes (including dramatic cuts in basic rates) were linked with the simultaneous labour market changes, the then Minister of Finance (the Hon Ruth Richardson) and Minister of Social Welfare (the Hon Jenny Shipley), were artless in contrast, emphasising the clear link between the 
ment-assisted scheme which the Director-General

\section{The statutory provisions}

Section $60 \mathrm{H}$ of the Social Security Act 1964 provides that a mandatory 26 week period of non-entitlement from unemployment benefit (commonly called a "stand down") may be imposed if the Director-General is satisfied that an applicant for an unemployment benefit has become unemployed without a good and sufficient reason or has voluntarily left a Government-assisted scheme without a good and sufficient reason (subs (2). The same mandatory period of non-entitlement applies if an applicant has become unemployed or ceased to be part of such a scheme by reason of misconduct (subs 3). In the case of misconduct, the Director-General has a discretion to pay the benefit conditionally on the basis that, should misconduct be proved at a later hearing by a court or other relevant authority, the benefit paid becomes repayable (subs (3)).

In practice the Director-General's discretion is delegated to departmental officers under $s 10$ of the 1964 Act. These officers are guided in the exercise of their functions under the legislation by a series of policy manuals. There is provision for review of delegated decisions by a benefit review committee (s 10A of the 1964 Act), each of which are constituted of two departmental officers and one community representative, and ultimately appeal to the independent Social Security Appeal Authority (Black, Harrop, Hughes, 1994, [1010A.2] - [1012R.2]).

Understandably, given the draconian nature of the penalty, the Social Security Appeal Authority has indicated that it is important to conduct the review process as quickly as possible in such cases (SSAA Decision No 34/93, unreported).

As the Main Benefits Manual notes, "there is no discretion about the length of non-entitlement (the provisions do not allow for any waming to be given)" (Department of Social Welfare, 1993a, para 10.5002).

We can now look at the grounds for imposing a standdown. These reflect, but are not identical to, those in the now-repealed s 60(6). The 26 week period of non-entitlement can be imposed under $\mathrm{s} 60 \mathrm{H}$ in relation to an applicant who:

* has become unemployed without a good and sufficient reason;

* or has become unemployed through misconduct.

\section{Voluntary unemployment}

Under s $60 \mathrm{H}(2)$ :

If the Director-General is satisfied that an applicant for a benefit -

(a) has voluntarily become unemployed without good and sufficient reason; or

(b) has been in receipt of payments under a Govem- considers analogous to a benefit and has voluntarily ceased to be part of that scheme without good and sufficient reason - the applicant shall not be entitled to a benefit for a period of 26 weeks commencing on the date on which the applicant's employment, or participation in that scheme, ceased, as the case may be.

Government assisted schemes include such schemes as the Conservation Corps. In addition, the Main Benefits Manual treats TOPS training courses, or other courses for which Training Benefit is paid, as being analogous to employment (para 10.5025). However, this is arguably incorrect. People committed to such a course are not "employed" in any technical sense of that word, thus rendering paragraph (a) inapplicable. Nor are they receiving payments "analogous to a benefit" under paragraph (b), since they are in receipt of a categorical benefit under Part I of the 1964 Act.

\section{Administrative guidelines on procedure}

The Main Benefits Manual instructs departmental staff applying s $60 \mathrm{H}(2)$ to take care to ensure that: personal contact is made with the applicant as it is not sufficient to decide a case solely on the employer's UB5 (Verification of employment) information;

* in cases of conflicting evidence the applicant must be given a chance to outline their version of the circumstances;

* the applicant gets the benefit of any doubt if the reason for leaving employment is not clear or agreed between the employer and the employee; and

* [staff are] sensitive when making enquiries (Department of Social Welfare, 1993a, para 10.5012)

The Appeal Authority decisions, discussed below, indicate that these guidelines are not always observed.

\section{"Voluntariness"}

The two key elements under s $60 \mathrm{H}$ are voluntariness and the absence of a good and sufficient reason. For an applicant to have become unemployed "voluntarily" prima facie implies a measure of choice and appears to preclude cases where the applicant is dismissed. This approach would confine the application of the stand-down in respect of dismissed employees to those dismissed for misconduct under s $60 \mathrm{H}$, discussed below. Against this, there are circumstances where an employee's behaviour might fall short of misconduct but nevertheless lead to a predictable dismissal. For example, repeated and unjustified absences due to minor "illness". Is an employee in this position having been dismissed - properly described as "voluntarily" unemployed?

British decisions, where the concept of voluntariness is adopted in the same context, have construed the word "voluntarily" broadly so as to extend to "cases of termina- 
tion by the employer which are instigated by the employee but which do not amount to misconduct" (Ogus and Barendt, 113). However, this approach, when applied to $s$ $60 \mathrm{H}$ in cases falling short of wilful repudiation of the contract of employment, would effectively read into the 1964 Act a "deeming" provision which is not statutorily provided for. Thus, in SSAA Decision No 107/92, unreported, the appellant had been dismissed after a letter of waming that he would lose his job if the standard of his work did not improve. The Department then immediately declined his application for an unemployment benefit, notwithstanding his argument that he was dismissed because of incompetence rather than misconduct. The Appeal Authority held that

Whatever the reasons for the appellant's dismissal, they did not amount to misconduct. They certainly gave the District Review Committee no basis at all for deciding the appellant had voluntarily become unemployed without good and sufficient reason. The fact that he was dismissed and would have returned to his employment but for that dismissal gives the lie to that finding since it is not possible to be dismissed and voluntarily become unemployed at the same time and from the same job.

The Department's policy as expressed in the Main Benefits Manual is to apply s $60 \mathrm{H}(2)$ also to those who have been self-employed and "who close or sell a viable business without a good and sufficient reason" (Department of Social Welfare, 1993a, para 10.5025).

Under the proviso to $58(1)$ of the 1964 Act, a person is not entitled to an unemployment benefit if the Director-General is satisfied that, amongst other things, that person is not employed because of a strike either by himself or herself or by fellow members of his or her union at the same place of employment. The Main Benefits Manual states that:

If employees are dismissed by an employer, their employment relationship terminates. They cannot be regarded as being on strike even though the circumstances for which they were dismissed may be regarded as constituting strike action. Such employees are not precluded by section 58(1), Social Security Act 1964 from receiving UB. However, the extended standdown period imposed by s $60 \mathrm{H}$, Social Security Act 1964 might apply, depending on the circumstances. (Department of Social Welfare, 1993a, para 10.7014)

By implication, then, the Department might treat dismissal because of strike action as being due either to voluntary unemployment or misconduct. Arguably, a dismissal cannot fall into the former category for the reasons elaborated above. It seems strongly questionable whether the statutory scheme, providing as it does for a separate category of non-entitlement in relation to strikes under s 58 , is properly observed by treating strikes as "misconduct" under $\mathrm{s} 60 \mathrm{H}$.

\section{"Good and sufficient reasons"}

What amounts to a "good and sufficient reason" is not defined and the phrase is not susceptible to any but the broadest of guidelines. Perhaps the clearest example is the forced resignation arising from a constructive dismissal. Such a dismissal occurs where the employer's behaviour either obliges or strongly tends to induce the worker to resign (Mazengarb, para III.21). The threat "Resign or be fired $^{\prime \prime}$ is an example of the former. Sexual harassment is an example of the latter and recognised as such by the Department of Social Welfare's Main Benefits Manual, so that an employee who leaves employment because of sexual harassment will not be deemed to have become voluntarily unemployed regardless of whether action is taken to report the problem (Department of Social Welfare, 1993a, para 10.5021).

Various features of existing employment may justify an employee in leaving. Examples given in the Main Benefits Manual include a requirement to travel an unreasonable distance to get to work, a job which is too heavy or one which falls outside the applicant's capabilities, unavailability of adequate child care arrangements or a significant change in conditions of employment (for example, the introduction of shift work for a person with a young family) (Department of Social Welfare, 1993a, para 10.5021). Some of these examples may amount to a constructive dismissal, depending on the circumstances.

In SSAA Decision No 150/92, unreported, the appellant had left work at an orchard six weeks before his employer estimated that work would have run out. His reasons for leaving were said to be accommodation difficulties since his mother, with whom he had been living, was due to leave New Zealand and his estimate that there were only a couple of weeks' work left. The Department imposed a 26 week stand down on the basis that the appellant had voluntarily become unemployed without a good and sufficient reason. Upholding the Department's action, the Appeal Authority held that:

Whatever the reason for leaving the job, it does not appear to relate to the job itself. There is no suggestion that the job was unsatisfactory, or that the appellant felt unsuited to it, or that relations between him and his employer or the other employees were less than satisfactory. These are the kinds of reasons that may constitute good and sufficient reason for becoming voluntarily unemployed under ss $60 \mathrm{H}$ Social Security Act 1964. That list is not exhaustive but it is difficult to include in it the reasons advanced by the appellant for leaving the job. If accomodation was a problem, it would remain so, regardless of whether he was employed in this particular area or not. If there were only a couple of weeks left to work then it is difficult to understand why the appellant did not remain on to work them out.

It is clear, therefore, that the appellant became voluntarily unemployed and that he did so without good and sufficient reason such that the Department was left with 
no alternative but to impose the mandatory stand down period provided in $\mathrm{s} 60 \mathrm{H}$ of the Act.

If the Appeal Authority was suggesting as a general principle that "good and sufficient reason" under s $60 \mathrm{H}$ must relate to the job itself, it was arguably incorrect. Such an approach would place an unwarranted gloss on the plain words of s $60 \mathrm{H}$, which do not limit the concept of "good and sufficient reason" in this way. There are many justifiable reasons for leaving employment which do not relate directly to the employment itself. As examples, one might consider an employee who moves out of the immediate area or who takes on additional child care responsibilities.

The decision also illustrates the essentially punitive nature of the mandatory 26 week stand down period. On the strongest case against the appellant, he left work six weeks before his employment would have terminated. Had he worked this period out, he might then have expected a stand down of two weeks under s 60 before becoming entitled to an unemployment benefit. In other words, his entitlement to an unemployment benefit would have arisen eight weeks after he actually left employment. As a consequence of the mandatory nature of the 26 week stand down, and assuming that he would not have found further work, the penalty for leaving six weeks early was deprivation of an unemployment benefit for a further eighteen weeks.

The Appeal Authority has since held that the test for what is a "good and sufficient reason" is objective. In SSAA Decision No 87/94, unreported, the a six month stand down had been imposed on the appellant after he had resigned from a job and moved to Christchurch from another centre partly because of insufficient prospects for career advancement and partly in order to pursue a relationship with his girlfriend, who lived in Christchurch. The Appeal Authority held that:

The rationale behind s 60H Social Security Act 1964 seems to be that if a person by their own actions becomes unemployed then they cannot rely on the State to provide them with an income until they find another job or six months has elapsed, whichever is the earlier. In other words, the provision contains a negative incentive to ensure that potential beneficiaries obtain alternative employment prior to terminating their current employment. If this is the case then it follows that a subjective assessment of whether employment has been surrendered for good and sufficient reason would all but render this provision nugatory.

The Appeal Authority went on to hold that, measured against the standard of what would generally be regarded as good and sufficient reasons, the reasons advanced by the appellant - whilst understandable - were insufficient and the imposition of the stand down was upheld.

The bargaining environment created by the Employment Contracts Act 1991 has affected decision-making in this area. In SSAA Decision No 19/93, unreported, the appellant had been laid off as a freezing worker at the end of the season and he was offered renewed employment only on condition that he signed an individual contract and that he would not use the Meatworkers Union as his bargaining agent. He believed that he would be unable to survive in this environment, without union services, and declined. The Department then treated him as being voluntarily unemployed and imposed a 26 week stand-down. The Appeal Authority reversed the decision, holding that:

The appellant felt completely unable to work effectively in the new work environment because of the difficulties that he perceived that he would have in communication with fellow workers and the management.

For this particular person that reason was a good and sufficient reason for failing to enter into the fresh employment contract because it created (again, for this particular person) a new and different employment environment and one in which the appellant believed he would not survive.

In this case, it is very doubtful whether the statutory criteria applied in any event. Due to the seasonal nature of the employment, in legal terms the applicant would have had his contract terminated at the end of the season (NZ Meat Workers, etc, Union Inc v Richmond Ltd, unreported, Employment Court, WLC 50/92). A point overlooked by the Department and, ultimately, the Appeal Authority is that he could not then be said to have become voluntarily "unemployed" because he refused a new contract. At the time of refusal, he was not employed.

This confusion is reflected in the Main Benefits Manual which subsumes under discussion of $\mathrm{s} 60 \mathrm{H}(2)$ the example of a person who "refuses an employment offer" carrying less than the minimum wage, the clear implication being that refusal of one job offer at minimum rates might justify the application of $s 60 \mathrm{H}(2)$. This is clearly not the case. Section $60 \mathrm{~J}(1)$ (b) confines the 26 week stand down in such circumstances to those who decline two offers of suitable employment without good and sufficient reason whilst receiving an unemployment benefit.

It may be noted that those leaving employment could be under an obligation to look for alternative work while still employed, since one condition of eligibility for an unemployment benefit under s 58 is that the applicant has taken reasonable steps to obtain suitable work. Presumably though, the reasonableness of such steps will depend on the measure of urgency entailed in the reason for leaving employment.

\section{Relationship with personal grievances}

Section $60 \mathrm{H}(3)$ provides for a benefit to be paid in relation to misconduct dismissals where the applicant is challenging the decision to dismiss through a court or analogous body, pending the decision on the challenge. There is no 
similar provision in relation to voluntary termination without a good and sufficient reason, although apparently 'voluntary' cases of termination by employees are frequently challenged through the personal grievance procedure as amounting to constructive dismissals (Mazengarb para [27.11]). The failure to ameliorate the immediate effects of a stand-down in these cases in the same manner as for "misconduct" dismissals is a major lacuna in the Act and heightens the need for extreme caution on the part of those administering the stand-down provisions. This is particularly the case because an employer faced with a personal grievance action based on alleged constructive dismissal is scarcely likely to admit to the Department that the employee concerned did not leave voluntarily, when that admission might be produced as evidence in the personal grievance hearing. Some employers might be tempted to falsify the reasons for the employee's departure with a view to enhancing their prospects of success in the personal grievance action (see, by analogy, Ashton v Shoreline Hotel, unreported, Employment Court, 12 April 1994, CEC 10/94).

\section{"Loss of employment because of misconduct as an employee"}

Under s $60 \mathrm{H}(3)$, a stand-down may be imposed if the Director-General is satisfied that an applicant for a benefit has lost his or her employment because of misconduct as an employee or has ceased to be part of a Governmentassisted scheme which the Director-General considers analogous to a benefit by reason of any misconduct. Once a decision is taken to impose a stand-down, the applicant is not entitled to a benefit for a period of 26 weeks commencing on the date on which the applicant's employment or participation in that scheme ceased.

There is one qualification. The Department of Social Welfare may concede entitlement to a benefit on the condition that if a Court, person, or body authorised by law to determine the matter determines the misconduct to be proved, the Director-General, in his or her discretion, may direct that any payments of the benefit made during the 26 weeks commencing on the date on which the applicant's employment or participation in the scheme ceased, shall be repayable. If the Director-General so directs, those payments are recoverable under section 86(1) of the 1964 Act as if they were instalments of a benefit in excess of the amount to which the beneficiary was entitled.

This qualification has been identified as one cause of the 'backlog' in grievance decisions in the Employment Tribunal. It has been argued by employers that, with the prospect of six months without income, applicants have little to lose from bringing a personal grievance claim which then entitles them to short term income support under the 1964 Act (Labour Select Committee, 41). No evidence has been advanced to support this assertion.

\section{Discretion}

It is clear that $\mathrm{s} 60 \mathrm{H}$ (3) confers a discretion on the Department. In SSAA Decision No 159/92, unreported, the Appeal Authority held in this context that:

The decision whether to impose the stand down pursuant to section $60 \mathrm{H}(3)$ involves a two-stage process: the Department must first determine whether an applicant has lost their employment because of their misconduct as an employee; it must then exercise a discretion whether to impose the stand down. Implicit in the first stage of this process is the necessity to conduct a thorough investigation into the reasons for an applicant's dismissal. It is not enough to rely uncritically upon an employer's version of the events leading up to the dismissal. That version must be put to the applicant and if there is any conflict further investigations must be made. This may involve seeking some advice from the relevant union or the Department of Labour as to whether the alleged behaviour leading to the dismissal amounts to misconduct.

On the facts in this case there was held to have been a complete failure by the Department in this respect: it had done no more than satisfy itself that the applicant had lost a place on an ACCESS course. The stand-down was imposed as soon as notice of this was received from the course provider, without asking for the appellant's version of events.

in SSAA Decision No 50/92, unreported, the Appeal Authority held that it was implicit in the second stage of the two-stage test elaborated above that the Department is required to consider the particular circumstances of each applicant's case in order to determine whether they were sufficiently serious to warrant a stand-down. In that case, a worker who had received two prior warnings for unrelated disciplinary matters was dismissed when he arrived at work late after injuring his wrist. The stand-down was imposed automatically without even contacting the employer. When the employer was contacted, the information he provided was not put to the appellant. When the appellant provided his version of events, it was disregarded. The Appeal Authority held that:

The Department has been able to provide no indication that it did any more than satisfy itself that the appellant lost his job because of misconduct. There appears to have been a complete failure to consider exercising the discretion at all, in that the stand-down was imposed simply upon confirmation that the appellant was dismissed for misconduct.

The Department has a responsibility to ensure that the discretion in $\mathrm{s} 60 \mathrm{H}(3)$ is seen to be exercised in cases of serious misconduct ... In the appellant's case it is at least arguable that he was dismissed because of his miscon- 
duct: the written waming received by him previously did not relate to the reason he was dismissed; the employer failed to follow its own procedures when it dismissed him; he had a valid reason for being late; he could have taken sick leave and thereby protected his job.

The need for caution is emphasised by the potential for employer's to abuse the power which $s 60 \mathrm{H}$ confers on them. In Ashton v Shoreline Hotel, unreported, Employment Court, 12 April 1994, CEC 10/94, Chief Judge Goddard found during a personal grievance hearing that an employer's claim to the Department that the employee had been given written warnings before being dismissed for misconduct was false, adding that:

The motive for making these particular false statements knowingly could only have been to harm the appellant by giving the Director-General of Social Welfare grounds to decline the appellant a benefit for the first 26 weeks of his unemployment ... The respondent may well have thought that if financially embarrassed, the appellant might be disabled from pursuing his personal grievance, or it may have been actuated by some antipathy towards the appellant.

\section{"Lost his or her employment"}

The first question in relation to the substance of $\mathrm{s} 60 \mathrm{H}(3)$ is the meaning of 'lost his or her employment'. The reference in the clause to an applicant who has 'lost his or her employment' by reason of misconduct is wide enough to include cases of disciplinary suspension where the contract still subsists. In practice, consideration of such cases under $\mathrm{s} 60 \mathrm{H}$ will be rare since few current employment contracts provide for disciplinary suspension and, of those that do, suspension is usually contemplated as a short-term stand-down pending investigation of a complaint and notification to the worker's union. Such action would fall within the 14 day stand-down period under $s 60$ of the 1964 Act.

\section{"As an employee"}

In referring to misconduct "as an employee", the clause carries the clear implication that the misconduct in question must arise out of, or in connection with, the employment. Thus, it will preclude cases where the dismissal is founded on misconduct outside the employment which nevertheless renders the worker unfit for his or her job. The most common examples of such misconduct are the dismissal of workers holding positions of trust following conviction for dishonesty and dismissals consequent on the loss of some necessary trade qualification, such as a licence, through disciplinary action by a professional or trade association.

The original internal guidelines in para 10.5031 of the Department of Social Welfare's Main Benefits Manual, operative until December 1993, were potentially too wide at this point, since they referred to "conviction of a criminal offence relevant to the employment", phraseology which would have covered criminal convictions sustained as the result of misconduct outside work as the result of which dismissal occured.

New guidelines, inserted in December 1993 (amendment No 9 to the Main Benefits Manual) now refer to "loss of employment because of theft or deliberate misuse of equipment, goods or money from the employer". In cases where there is no criminal prosecution for such behaviour, staff are instructed to seek legal advice from a departmental solicitor (Department of Social Welfare, 1993a, para 10.5031).

\section{"Misconduct"}

What does 'because of misconduct' mean? Must misconduct be the sole factor? The dominant reason? Or just one of a number of reasons? English decisions suggest that the misconduct must at least be a necessary element in the decision to dismiss (Calvert; Ogus and Barendt).

The key question is the meaning of the word 'misconduct' itself. In terms of the contract of employment 'misconduct' is normally interpreted as referring to "conduct so seriously in breach of the contract that by standards of faimess and justice the employer should not be bound to continue the employment" (North $\mathbf{v}$ Television Corporation Ltd (1977) 11 ALR 599). This is reflected in the instructons to departmental staff in the Main Benefits Manual (Department of Social Welfare, 1993a, para 10.5031).

There is no fixed rule of law defining the degree of misconduct justifying dismissal (Clouston \& Co v Corry [1906] AC 122, cited with approval in North Island Groceries Ltd v Hewin [1982] 2 NZLR 176). Whilst it was said in North's case that it would be "difficult to imagine a case of serious and wilful neglect which would not itself constitute misconduct", any lesser degree of neglect would normally not be included in that term.

Because the courts have tended to concentrate on whether the employee's action or inaction justified the employer's decision to terminate the contract, there has been no real need to define the concept of misconduct precisely or to distinguish it from other substantive causes for dismissal which lack the element of 'wilfulness' which seems to accompany most misconduct cases. For example, since extreme cases of negligence can give rise to a justified dismissal, there has been no need to decide whether, say, an oil tanker driver who lights a cigarette at a filling station is guilty of misconduct or negligence. One problem with $s 60 \mathrm{H}(3)$ is that much can then turn on the arbitrary classification used by the adjudicator or judge in this context.

In the context of $s 60 \mathrm{H}(3)$, there is much to be said for confining the term "misconduct" to the meaning which it has acquired in employment law. This is particularly so 
given the link between the stand-down period and determinations by any "Court, person or body authorised by law" as to whether the misconduct has been proved. The usual forum here will be the Employment Tribunal or the Employment Court, in the course of a personal grievance complaint under the Employment Contracts Act 1991. The wording would also cover an arbitrator operating under an alternative grievance procedure in an employment contract.

The Department of Social Welfare's Main Benefits Manual originally gave as one example of misconduct "failure to supply output or quality of work having regard to the applicant's capabilities" (Department of Social Welfare, 1993a, para 10.5031). This bordered on covering dismissal for lack of general competence or 'nous', which was held by the Court of Appeal to be outside the normal boundaries of misconduct justifying summary dismissal in Hewin's case. In new policy guidelines, operative from December 1993 (amendment no 9 to the Main Benefits Manual), that paragraph now refers to: "loss of employment because of deliberate failure to supply output or quality of work having regard to the applicant's capabilities, rendering the conduct of the worker incompatible with the faithful discharge of his or her duty to the employer."

The Manual adds that: "There could be situations where an employer is entitled under employment law to dismiss a worker for misconduct, but where the 26-week period of non-entitlement should not be imposed. For example, dismissal for a lack of ability to do the job, where the person had been workng to the best of ther ability."

Whilst the distinction between deliberately bad work and simple lack of ability is apt, it should be noted that cases falling into the latter class have never been regarded as constituting misconduct for the purposes of employment law (see the treatment of Hewin's case, above).

Nothing is to be gained from listing illustrations of misconduct. Examples abound in employment law (Mazengarb, paras [27.27] and following). The Department of Social Welfare's Main Benefits Manual lists "persistent failure to follow prescribed safety practices", and loss of employment because of assault on a fellow worker or destruction of plant which amounts to serious misconduct. Again, if there is no criminal prosecution for such behaviour, staff are instructed to seek legal advice (Department of Social Welfare, 1993a, para 10.5031). A further example provided by the Manual is "loss of employment because of unauthorised absence for a lengthy period or persistent absenteeism". In SSAA Decision 9/93, unreported, in which a worker was dismissed after absence following a final warning, the imposition of a stand down was upheld by the Appeal Authority.

In dealing with the stand-down for misconduct, the Main Benefits Manual stresses that:
* departmental staff should seek legal advice whenever there is doubt in assessing such cases (Department of Social Welfare, 1993a, para 10.5031);

* that the examples in the Manual are only examples which could warrant dismissal (Department of Social Welfare, 1993a, para 10.5031); and that

* each case must be considered on its individual merits (Department of Social Welfare, 1993a, para 10.5033).

\section{The employer's opinion}

When a person applies for an unemployment benefit, the past employer will be sent a form UB 5, "Verification of Employment", and asked the reasons for the termination of employment. In relation to this process, the Main Benefits Manual notes that the employer will often request confidentiality when completing form UB5 but that this cannot be guaranteed because of the Official Information Act 1982 . If there is conflicting evidence, the employee must be advised of the reasons given by the employer if those reasons are the basis for the decision, despite the employer's request for confidentiality. Staff are told to give the applicant the benefit of the doubt where the actual cause of the dismissal is unclear (Department of Social Welfare, 1993a, para 10.5034). The Privacy Act 1993 also requires disclosure unless there is good reason to withhold information (Roth, 1994). There is also the right to a written statement of reasons for dismissal under $\mathrm{s} 38$ of the Employment Contracts Act 1991.

\section{Policy considerations}

As we have seen, the Department has a discretion whether to impose the stand-down where misconduct has been found to have led to dismissal. The boundaries of that discretion are not set out in the legislation or in the Main Benefits Manual. However, the underlying policy behind the stand-down could be a relevant factor. Ogus and Barendt, 1980, point out that there might be three different approaches. First, there is 'punishment': that the dismissed worker must suffer for having transgressed. Secondly, there is 'suitability': that the benefit is only there for those whose unemployment is due to external forces. Thirdly, there is 'voluntary unemployment': that the benefit is not there to support a worker who knew, or ought to have known, that his or her job would be lost as the result of misconduct. Depending upon which basis is selected, different results might follow.

Of the three, the third approach seems most in line with the Government's thinking. Introducing the bill, the Minister of Social Welfare described the stand-down as operating where workers "put their own jobs in jeopardy through misconduct" and the Minister of Employment described the measure as involving "a massive disincentive to leaving employment for the wrong reasons" (Hansard, Vol 511, p 463).

If the third approach does reflect the underlying policy, then it might be relevant to the exercise of the discretion to 
ask whether the worker knew, or ought to have known, that his or her job would be lost as the result of the alleged misconduct (for example, Was there a warning? Was the misconduct so gross that dismissal was an obvious outcome? etc). The Department of Social Welfare's Main Benefits Manual suggests that the misconduct must have been sufficiently serious to have justified the dismissal (Department of Social Welfare, 1993a, para 10.5030). This approach has also been taken by the Appeal Authority which has indicated that an element of the proper exercise of discretion under s $60 \mathrm{H}(3)$ is to ask whether the conduct in question was sufficiently serious (and the consequences sufficiently foreseeable) to justify the exercise of the discretion to impose the stand down. In SSAA Decision No 34/93, unreported, because the appellant was taken to know that theft as a servant would lead almost invariably to dismissal, this being a 'widely accepted consequence', a stand down after dismissal on these grounds was upheld.

\section{The effect of contested dismissals}

Paragraph (d) enables the benefit to be granted where a contested dismissal which is proceeding under the personal grievance or other dispute resolution procedure, on the basis that the applicant agrees to repay all benefit paid if the misconduct is then proved in those proceedings. The Main Benefits Manual requires that the agreement be in writing (Department of Social Welfare, 1993a, para 10.5036).

There are a number of unresolved issues at this point (Black, Harrop, Hughes, 1994, para 1060H.16). First, what is the correct approach if the Tribunal or the Court finds the misconduct was proved, but that it did not justify dismissal? Paragraph (d) talks only of mandatory recovery of benefit where the misconduct has been proved, not where dismissal was justified. Suppose that an employer dismisses for misconduct which the Tribunal or the Court finds to be proved, but to be only trivial and not to supply justification for termination of the employment? This occurs regularly in practice. The apparent rationale for recovering the benefit ('voluntary unemployment') disappears, but the mandatory nature of paragraph (d) means that the benefit is then repayable. This is clearly an undesirable result.

Secondly, there is no procedure analogous to the grievance procedure for determining the correctness of a 'dismissal' from a Government-assisted scheme (s $60 \mathrm{H}(3)(\mathrm{b})$ ). If it cannot operate in these circumstances, can the discretion then properly be exercised under s $60 \mathrm{H}(3)(\mathrm{c})$ ? In other words, is there a discretion at all? (Cheyne, 1992, 15)

Thirdly, in terms of general policy, reliance on the findings of the Employment Tribunal or of the Employment Court may give rise to problems in terms of issue estoppel. There are different questions of law involved. The Tribunal and the Court are concerned to ascertain whether the employer's conduct was justified. But for the purposes of s $60 \mathrm{H}(3)$ the question seems to be entirely one of fact: What moti- vated the employer, regardless of justification? Also, the burden of proof is different in the Employment Tribunal and Employment Court from that in the Social Security Appeal Authority, in which contemporaneous proceedings may be launched. What happens, for example, if the Social Security Appeal Authority overturns a departmental decision on the basis that there was no misconduct, but the Employment Tribunal finds that there was? Should one set of proceedings await the other and, if so, which? The problem will be exacerbated where theft is alleged and the criminal courts become involved.

\section{Ameliorating provisions}

Under s $60 \mathrm{~K}$ of the $1964 \mathrm{Act}$, a stand-down imposed on a person because of voluntary unemployment, misconduct or failure to seek or to accept work will lapse if that person undertakes full employment for a total of six weeks during the 26 week period of non-entitlement. 'Full employment' for the purposes of $s 60 \mathrm{~K}$ is defined as an average of at least 30 hours a week ( 33 of the $1964 \mathrm{Act}$ ) and the weeks do not have to be worked in one block. The concept is defined to include both employment under a contract of service and self-employment carried on for pecuniary profit (although no actual profit is required by the definition). A new application after the six week period will attract the usual two week stand-down.

Under s 60KA unemployment benefit can also be paid to a person who is subject to a stand-down if that person secures a place on a Community Taskforce programme and participates satisfactorily. After six weeks of satisfactory participation in the programme, the remainder of the stand down lapses (s $60 \mathrm{KA}(3)$ ). If participation is for less than six weeks, the period on the programme is deducted from the 26 week period (s 60KA(2)). The DirectorGeneral of Social Welfare has the authority to determine what is, or is not, satisfactory participation (s $60 \mathrm{KA}(5))$.

Under s 60L(1) of the 1964 Act, persons stood down from unemployment benefit are also precluded from receiving emergency benefit, accommodation benefit or special benefit during the stand-down period. Section 60L provides that the 'spouse' of a person who is disqualified from receiving an unemployment benefit by reason of strike action or subject to a 26 week stand-down is entitled to an unemployment benefit at a special rate (subs (1)). This does not apply to the redundancy stand-down (subs (2)).

Clearly, as well as penalising the applicant for a benefit, the stand-down rule also penalises the applicant's family. Normally, such a partner would qualify for an unemployment benefit in their own right. However, s $60 \mathrm{~L}$ (2) deals with the position of the partner of a person who is either not eligible because of strike action or has been stood down for misconduct, voluntary unemployment or refusal to seek work. The partner may be paid unemployment benefit at a special rate of half the married rate with no children during the period of non-entitlement (ie, at present $\$ 109.25$ per week). Entitlement to accommodation supplement is 
Hardship assistance by way of special needs grant under s 124 of the 1964 Act may be available, although the conditions for qualifying are stringent. The amount of such payments, and the qualifying conditions, are set out by Ministerial Direction under s 5 of the 1964 Act (reproduced in the Appendices to Black, Harrop, Hughes, 1994).

\section{Social security and grievance awards}

Section 71 of the Social Security Act 1964 makes provision for circumstances in which a person has received compensation or damages in respect of disability, disease, or dismissal, enabling the benefit paid to take account of such a payment or, where the payment is prospective, to enable recovery of the benefit paid once the compensation has been received. Thus, where a person is proceeding with a personal grievance for unjustifiable dismissal, an unemployment benefit may be granted subject to the condition that the benefit will be repaid out of any compensation received by the grievant (s 71(2)). 'Compensation' in this section is probably to be read in its generic sense as including awards of reimbursement, rather than as relating to compensation properly so called under $s 40$ of the Employment Contracts Act 1991. Thus, where such a condition is attached, the Tribunal and the Court should not, in principle, deduct a sum equivalent to any unemployment benefit paid from an award of compensation or reimbursement (see, by analogy, United Food and Chemical Workers Union v J Wattie Foods Ltd, unreported, Employment Court, 12 December 1992, WEC 21/92).

In order for $\mathrm{s} 71$ to operate, the grant of benefit must have been conditional at the outset. Thus, in SSAA Decision No 67/93, unreported, where the Department had not made it apparent to the appellant that her benefit was conditional on such repayment, the Appeal Authority held that if the Director-General decides to exercise the discretion in favour of an applicant he/she must also impose the condition of repayment (of some or all of the benefit subsequently received) at the time of grant. This would appear to place an onus on the Department to record the condition imposed with the advice of the grant of benefit and the Director-General has no power in $\mathrm{s} 71$ to impose the condition of repayment subsequent to the granting of the benefit.

There is also an inter-relationship between $\mathrm{s} 71$ and $\mathrm{s}$ $60 \mathrm{H}(3)$ (d). Under the latter section, as we have seen, an unemployment benefit may be paid where an employee has been dismissed for alleged misconduct, on condition that it be repaid if the misconduct is found to be proved.

'Compensation or damages' under s 71(2) includes ex gratia payments made in settlement. This is presumably to defeat, for social security purposes, the practice which had developed under earlier legislation of settling personal claims without an identifiable element of wage reimbursement in the settlement figure, so as to avoid taxation on
Social Security Appeal Authority Decision No 60/94, was an appeal from a decision to treat a lump sum payment from an employer as compensation for loss of income under 871 . On 4 June 1993, the appellant had tendered his resignation to the employer following some weeks of negotiation concerning his claim that he was being treated unfairly by his immediate superior. The settlement included a month's salary in lieu of notice, 11 days holiday pay, a lump sum representing three months' salary and a performance bonus of $100 \%$ of that to which he would have been entitled for the period 1 April 1993 to 4 October 1993. The principal issue was the Department's decision to treat the lump sum as representing salary paid up to 4 October 1993. The effect of this, combined with the "high income' stand down under s 80B meant that the appellant was disqualified from receiving an unemployment benefit until 31 December, some six months after he had left the employment.

The appellant argued that the lump sum should not be treated as lost income since it had been spent on lawyers' fees and removal costs incurred after his resignation. It was, he argued, compensation for a prospective personal grievance for discrimination which he would otherwise have brought against his former employer. The Department conceded that the amount expended on obtaining compensation could be deducted from the total compensation received and included in this figure both the lawyers' fees and the removal costs. However, the effect of this concession was merely to reduce the proportion of the lump sum deemed to be in compensation for loss of expectation of employment.

The Social Security Appeal Authority held on this point that:

Notwithstanding the careful way in which the appellant's settlement with his former employer was worded it is clear from other evidence provided that the amount which he received to settle his personal grievance was equivalent to three months salary. Part of the calculation involved the payment of $100 \%$ of the performance bonus to which the appellant would have been entitled for the period of 1 April to 4 October 1993. If that evidence was not available the Department remained entitled to calculate the same or a similar period for which it regarded the appellant as not entitled to a benefit because of the deeming provisions of $\mathrm{s} 71(1)(\mathrm{a})$ and the provisions of $s 71$ (2) of the Act. The combined effect of these particular provisions enables the Department to deem a certain period as covered by compensation received and it presumably would have done so by simply dividing the total received by the appellant's monthly base salary.

The Appeal Authority held that the Department had exercised its discretion reasonably in taking the appellant's expenses on obtaining compensation into account and 
deducting them from the total received. The Authority added "The fact that the appellant had spent the whole of the amount received in compensation before he was entitled to receive the benefit is not relevant to the exercise of the discretion".

This decision illustrates that those framing settlements of personal grievance cases have very limited options under s 71 of the 1964 Act where the level of compensation is pegged to periodic wage or salary payments. On the facts of the case, it is difficult to see how the appellant could have escaped that provision. However, the ability simply to divide a settlement total by the applicant's monthly or weekly base salary or wage should in principle be restricted where the settlement figure expressly includes a compensatory element for humiliation, emotional trauma, etc, and this is not a sham to disguise a wage-based settlement. Section 71(1)(a) clearly refers to the period of "loss of expectation of employment in respect of which the compensation or damages have been paid". Compensation which is genuinely meant to cover humiliation or other emotional loss should not be included in the Department's calculations and to do so would arguably be an invalid exercise of the discretion. The inclusion of ex gratia payments within the definition of "compensation or damages" in subs (3) of s 71 does not override the need to assess the real basis of the payment.

\section{Future research}

This paper has aimed to provide a practical sketch of how the law is operating in this particular area. Since the bulk of the paper is an updated version of material in current, and forthcoming, practitioner's texts (Mazengarb, and Black, Harrop, Hughes, respectively), theoretical perspectives have not been advanced. There is a need for such a detailed theoretical study, particularly in the light of the sudden and marked changes in approach both to employment law and the law of social security in the past three years. Studies of the relationship between the changes to the social security system and this country's international treaty obligations are also in their infancy (Hunt, 1994). A detailed consideration of the formation and implementation of social security policy in the years 1990-1991 is also long overdue.

\section{References}

Black J, Harrop S and Hughes J, 1994 Income support law and practice, Butterworths of New Zealand Ltd, Wellington.

Calvert, H, 1978 Social security law, London.

Cheyne, P, 1992 The implications of the misconduct stand-down rule in the unemployment benefit $I n$ dustrial Law Bulletin, : 15-17

Department of Social Welfare, 1971, Background paper No 10 to the Royal Commission on Social Secu- rity), mimeo.

Department of Social Welfare, 1993a, Main Benefits Manual, Department of Social Welfare, Wellington.

Hughes, J. 1990, Labour Law in New Zealand, Law Book Co. Ltd, Sydney.

Hunt, P, 1994, Reclaiming economic, social and cultural rights, 1993, 1 Waikato Law Review :14-33

Labour Select Committee, 1993, Report of the Labour Committee on the Inquiry into the Effects of the Employment Contracts Act 1991 on the New Zealand Labour Market, Appendices to the Journals of the House of Representatives I.9D.

Mazengarb, 1993, Mazengarb's Employment Law, 5th ed, Butterworths of New Zealand Ltd, Wellington.

NZ Treasury, 1990, Brief to the incoming government, mimeo.

Ogus, A.I., and Barendt E.M., 1980 The Law of Social Security, Sweet \& Maxwell Ltd, London.

Richardson, R, 1991, Interview in National Business Review, January: 16-19.

Roth, P, 1994, Privacy law and practice, Butterworths of New Zealand Ltd, Wellington.

Shipley, J.

1990a Ministers of Finance and Social Welfare, "Report to the Cabinet Strategy Committee".

1991a Speech notes on the introduction of the Social Security Amendment Bill.

1991b Social assistance: welfare that works Wellington, Government Printer.

Stephens, T. 1992 Budgeting with the benefit cuts. In Boston J and Dalziel P (eds) A decent society? Essays in response to National's economic and social policies, Oxford University Press, Wellington.

\section{Author}

John Hughes is a Senior Lecturer in the School of Law, University of Canterbury, Private Bag 4800, Christchurch 